\title{
Geleneksel Van Evlerinin Cephe Özellikleri ve Tipolojisi Üzerine Bir İnceleme
}

\author{
Gökhan UŞMA ${ }^{* 1}$, Nur URFALIOĞLU ${ }^{2}$ \\ ${ }^{1}$ Adana Bilim ve Teknoloji Üniversitesi, Mimarlık ve Tasarım Fakültesi, Mimarlık Bölümü, \\ Adana \\ ${ }^{2}$ Yıldız Teknik Üniversitesi, Mimarlık Fakültesi, Mimarlık Bölümü, İstanbul
}

Geliş tarihi: 31.10.2017_ Kabul tarihi: 14.03 .2018

$\ddot{\mathbf{O} z}$

Mimaride cephe elemanlarının kullanım biçimi, malzemesi, oranları, birbirleriyle olan ilişkileri cephenin kimliğini oluşturur. Yerel mimaride cephe kimliğinin oluşumu çevresel faktörlere bağlı kalarak bu çerçevede kısıtlanmışken, farklı dönemlerde karmaşık ve yoğun süslemelerle, kullanılan malzemelerle ihtişamın simgesi olmuştur. Yapının kullanım amacı ve gereksinimler cephenin oluşumuna yön vermiştir. Bu kapsamda cepheyi simgesel bir ifade aracı olarak görmek mümkündür. Bu çalışmanın amacı, tarihsel süreçte birçok medeniyete ev sahipliği yapmış Anadolu kentlerinden biri olan Van'ın kent dokusunun oluşumunda önemli bir yeri olan geleneksel Van evlerini bahsedilen kapsamda değerlendirip, oluşumunda etkili olan faktörleri de dikkate alarak cephe özellikleri ve tipolojisi üzerine bir inceleme yapmaktır.

Anahtar Kelimeler: Geleneksel Van evleri, Cephe, Cephe özellikleri, Van, Koruma

\section{An Analysis of the Façade Features and Typology of Traditional Van Houses}

\begin{abstract}
In architecture, the form of the façade elements, the material, the proportions and their relationship with each other constitute the identity of the facade. While the formation of the façade identity in the vernacular architecture depends on the environmental factors and is restricted in this frame, it has become a symbol of the magnificence with the materials used intricately and intensely at different periods. The purpose and necessity of construction has led to the formation of the façade. In this context, we can see the facade as a symbolic expression tool. The aim of this study is to evaluate the characteristics of the traditional Van houses and examine the features of the façade of traditional Van houses, which has an important place in the formation of urban identity of Van which is one of the Anatolian cities that hosted many civilizations in the historical process.
\end{abstract}

Keywords: Traditional Van houses, Facade, Facade features, Van, Conservation

*Sorumlu yazar (Corresponding author): Gökhan UŞMA, gusma@adanabtu.edu.tr 


\section{GíRiş}

Var olduğu tarihten günümüze insanlar barınma, beslenme, uyuma gibi temel ihtiyaçlarını karşılamak için yaşam alanları oluşturmuştur. $\mathrm{Bu}$ yaşam alanları önceden doğanın sağladığı imkanlar dahilinde mağara vb. doğal alanlar iken, insanın üretme, inşa etme yeteneklerine ulaşması ve yerleşik hayata geçmesiyle birlikte kendi inşa ettiği yapılara dönüşmeye başlamıştır. Zaman içerisinde bu yaşam birimlerinin belli düzende bir araya gelmesiyle de sokak, meydan ve mahalle gibi daha büyük yerleşim birimleri ortaya çıkmıştır [1].

İlk yerleşim yerlerinin Mezopotamya'da ve Güneydoğu Anadolu'da olduğu bilinmektedir. Bu bağlamda Geleneksel Türk evlerinin tipik özelliklerinin ilk yerleşmelerden izler taşıdığ söylenebilir. Güneydoğu Anadolu'da bulunan yerleşim tarihi 10000 y1l öncesine dayanan Çayönü kazılarında elde edilen bulgularda, Anadolu evinin tipik özelliklerinden biri olan; evin, havalandırmak için yerden biraz yükseğe kaldırılmasının o dönemlerde başladığı görülmüştür. Konya'nın güneydoğusunda bulunan ve geçmişi yaklaşık 7500 yıl öncesine dayanan Çatalhöyük'teki yerleşmede düz damlar ve bunların bir dolaşım ve çalışma alanı olarak kullanılması yine Anadolu'da aynı şekilde devam etmiştir [2]. Bu örneklerde de görüldüğü gibi mimari yapı teknikleri ve elemanlarının oluşumunu birkaç yüzyıla dayandırmak doğru bir yaklaşım olmayacaktır. Geleneksel Türk evlerinin genel özelliklerinin, tarihi süreç içerisinde süregelen bir kültür birikimiyle meydana geldiği anlaşılmaktadır. Anadolu'nun coğrafi ve iklimsel özellikleri de konut yapımında her dönemde etkili faktörler olmuştur. Yapım tekniği, uygulama yöntemleri, kullanılan malzeme ve cephe şekillenişinde yörenin coğrafi ve iklim özelliklerinin etkisi görülmektedir. Yörede hâkim olan inanç sistemi, ekonomik şartlar, yaşam tarzı gibi durumlarında etkili olması ve tüm bu faktörlerin bir araya gelmesi, Anadolu'nun farklı yerlerinde mimari çerçevede farklı sonuçlar doğmasına neden olmuştur [3].

İçinde barındırdığı konut dokusu ve korunamayan yapıların genel özellikleri incelendiğinde, Anadolu konut mimarisinin karakteristik özelliklerini büyük ölçüde yansıtan Van kenti, tarih boyunca birçok medeniyete ev sahipliği yapmış, tarihi, kültürü ve mimari mirasıyla önemli bir yerleşim yeridir. Van tarihinin yazı öncesi devire kadar uzandığ 1 yapılan arkeolojik kazılar ve çalışmalar sonucunda bilinmektedir. Yapılan bu araştırmalar ışığında Van ve çevresinde yapılaşmanın Kalkolitik devire dayandığını ve bu dönemden süregelen bir kültür birikiminin bölgede hâkim olduğunu söylemek mümkündür [4]. Farklı medeniyetler farklı mimari yapı tiplerini meydana getirirken, birbirleriyle olan etkileşimleri de Van kent dokusunun oluşmasında önemli bir etkiye sahiptir. Van konut mimarisi ve geleneksel Van evleri üzerine yapılan daha önceki çalışmalar incelendiğinde, çalışmaların yüzeysel kaldığı ve geleneksel Van evlerinden sadece bir tanesinin (Yörükler evi) tescillendiği, 2011 depremi sonrası ayakta kalmayı başarabilmiş diğer evlerle ilgili herhangi bir çalışma yapılmadığı görülmüştür [5]. $\mathrm{Bu}$ çalışmanın amacı ise geleneksel Van evlerini mimari özellikleri çerçevesinde ele alıp, tarihi kent dokusunun önemli unsurlarından biri olan konut cephelerinin özellikleri üzerine inceleme yaparak; bu incelemeler sonucunda bir cephe tipolojisi ortaya çıkarmaktır. Bu kapsamda Van'ın Tuşba ve İpekyolu (eski Van Merkez ilçesi) ilçelerinde bulunan ayakta kalmayı başarabilmiş az sayıda geleneksel konut ve 2011 depremi sonrası ya da daha öncesinde yıkılmış olan 21 adet konut incelenmiştir.

Çalışma yöntemi olarak, konu ile ilgili literatür taraması, var olan yapılar için saha çalışması yapılarak fotoğraf ile belgeleme sağlanmıştır. Yıkılmış olan evler için arşiv çalışması yapılmıştır. Sorumlu kamu kurumlarından yapıların tescil durumu hakkında bilgi alınmıştır.

Çalışma beş ana bölümden oluşmaktadır. Giriş bölümünde tarihsel süreçte konut mimarisinin oluşumu ve Anadolu'da konut mimarisini oluşturan/etkileyen faktörler ele alındıktan sonra, çalışma alanı olan Van İli'nin konut dokusu hakkında bilgi verilmiştir. Çalışmanın amacı, kapsamı ve yöntemi açıklanmıştır. İkinci bölümde 
mimaride cephe kavramı ele alınarak, cephe elemanının tarihsel süreç içindeki durumu ve geleneksel Türk evlerinin cephe özellikleri incelenmiştir. Üçüncü bölümde Van'ın coğrafyası ve kısa tarihine değinilip kentteki konut mimarisi ele alındiktan sonra Geleneksel Van Evleri'nin cephe özellikleri incelenip, cephe tipolojisi ortaya çıkarılmıştır. Dördüncü bölümde ise kent kimliğini oluşturan değerler ve bu değerlerden biri olan cephe elemanının tarihsel süreçteki durumu, çalışma sonunda elde edilen bulgular neticesinde irdelenmiş olup yapılan çalışmada ulaşılan bulguların genel değerlendirmesi yapılmıştır. Ulaşılan sonuç ve konu hakkındaki öneriler açıklanmıştır.

\section{MIMARIDE CEPHE KAVRAMI VE GELENEKSEL TÜRK EVLERINDE CEPHE}

Cephe, kentsel dokunun oluşumunun bir parçası ve yapının dişarıdan algılandığı diş yüzüdür. Kavram olarak, ön yüz veya bina yüzüne dik doğrultuda sonsuzdan bakılan görünüş olarak da tanımlanmaktadır [6]. Görünüş anlamının yanı sıra, bina-kent arasında görsel ve programatik bir sınırı da ifade etmektedir [7]. Binanın mimari dilinin bir yansıması olan cephe, bazı durumlarda yapının kent kullanıcısı tarafından görülebilen tek mimari ögesidir. Kent kullanıcısının cepheyi okuma ve algılama şekli insan-kitap ilişkisindeki duruma benzerdir. Kent kullanıcısı cepheyi algılar, okumaya başlar, cephe ile kullanıcı zihni arasında bir etkileşim olur ve zihin cepheden aldığ daha sonra kullanmak için saklar [8-10].

Cephe, mimaride her dönemde önemli bir yere sahip olmuştur. Kavram olarak 'cephe'nin içeriği farklı dönemlerde değişik yaklaşımlara sahip olsa da genel ifadesi aynı kalmıştır. Uğur Tanyeli, tarih öncesi dönemde cephe kavramının mimarlıkta bir olgu olmadığını ve bazı yerel toplulukların yapı yüzeylerine çizdiği resimsel bezemelerle sınırlı olduğunu söylemektedir [11]. Rönesans Dönemi'nde Alberti'nin çalışmaları ve Vitrivius'un çevirileri ile cephe kavramı mimarlıkta daha önemli bir yer edinmiştir. 19. yüzyıl ve 20. yüzyıl apartmanlarının en önemli mimari ögelerinden biri olarak bu konutların mimari dilini aktaran cepheler, kentsel mekânın parçası olmuştur. Cephe, kent kullanıcısıyla mimari iletişsim yetisi en yüksek olan yapı elemanı olarak tanımlanabilir [12]. Bu dönemlerde bitişik nizam İstanbul apartmanlarında cephenin yapıların mimarisinde dışa aktarılan en önemli yapı elemanı olduğu görülmektedir (Şekil 1). Bu kapsamda, cephenin kentsel mekanların tanımlanmasındaki etkisinin de büyük olduğu anlaşılmaktadır.

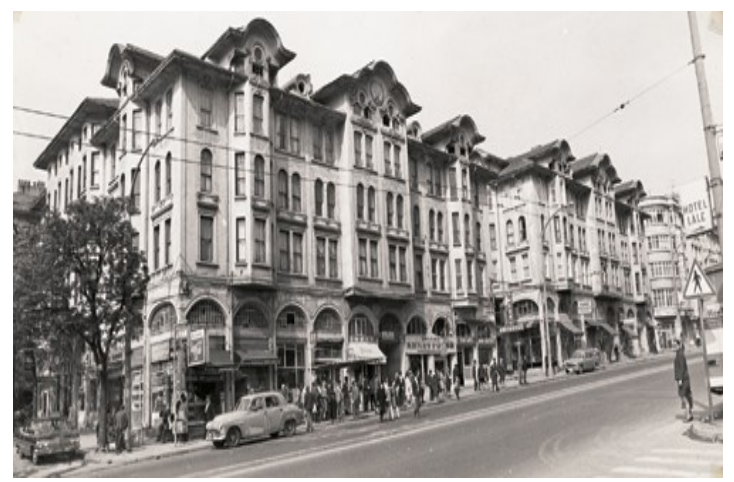

Şekil 1. Tayyare Apartmanlar1-İstanbul [12]

Cepheyi de oluşturan ve şekillendiren mimari elemanlar vardır. $\mathrm{Bu}$ elemanların ortak bir dil oluşturarak birbirine bağlanmasıyla cephenin kompozisyonu ortaya çıkmaktadır. Cephe kompozisyonlarının farklı oluşum biçimleri vardır. Yerel mimaride bu oluşum kentin coğrafi yapısı, bölgenin iklim özellikleri ve sosyo-ekonomik yapısı ile ilişkilidir.

\subsection{Geleneksel Türk Evlerinin Genel Özellikleri}

Geleneksel Türk Evi, Osmanlı Devleti'nin sahip olduğu toprak sınırları içinde var olmuş ve gelişmiş; kendine has özellikleri içinde barındıran, 500 yıl geçmişe dayanan bir ev tipidir. İlk olarak Anadolu'da kendi kimliğini oluşturmuş, sonrasında Osmanlı toprakları sınırları içinde Balkanlar'da ve Avrupa'nın diğer yerlerinde yer edinmiştir. Yerleştiği topraklarda 15 . ve 16. yüzyıldan itibaren diğer ev tiplerinin yerini almaya 
başlamıştır. 17. ve 18. yüzyıllar ise Türk evinin en çok yayılma gösterdiği dönemler olmuştur [13].

Plan şeması olarak sofasız; dış, iç ve orta sofalı plan şemaları görülmektedir (Şekil 2). Odaların sofanın uzantısıyla ayrı mekanlar haline gelmesi ve aynı zamanda birbirlerine bağlanması Türk evi plan tiplerinin en önemli ve kendine has özelliklerinin başında gelir [13,14]. Türk evi genel olarak tek katlı veya iki katlıdır. İki katlılarda alt kat genellikle servis mekanları, üretim ürünlerinin bulunduğu ambar, samanlık ve bazı durumlarda ahırın bulunduğu mekanlardan oluşurken üst kat yaşama alanlarını barındırır. Türk evinin bir diğer özgün özelliği de içten dışa doğru düşünülerek inşa edilmesidir. Modern mimarlık akımında söylendiği şekliyle formun fonksiyonu takip etmesidir. $\mathrm{Bu}$ durum Türk evinde kendiliğinden gelişen bir durum olarak karşımıza çıkar. Burada dışın önemsenmediği anlamı çıkarılmamalıdır [2].

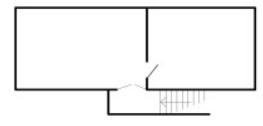

(a)

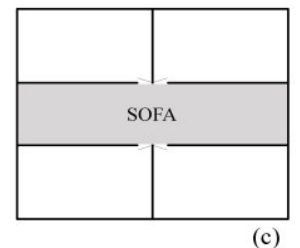

(c)

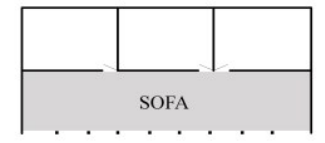

(b)

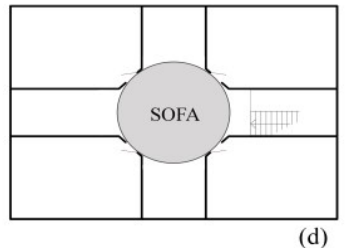

(d)
Şekil 2. Geleneksel Türk evi plan şeması örnekleri a) Sofasız plan tipi b) Dış sofalı plan tipi c) İç sofalı plan tipi d) Orta sofalı plan tipi (Sedad Hakkı Eldem'e Göre)

Yapım tekniği olarak en sık rastlananı ahşap çatkı arası dolgu veya bağdadidir. Yapım tekniği zengin ve fakir halk evleri arasında bir fark göstermez. İkisi arasındaki fark, yapının programının büyüklüğü ve süslemelerde ortaya çıkar. Geleneksel Türk evlerinde temel yapı malzemeleri ahşap, taş, güneşte kurutulmuş tuğladır. Anadolu'da bozkırın hakim olduğu bölgelerde kerpiç, yapı malzemesi olarak sıklıkla kullanılmıştır [15].
Bölgenin sosyo-kültürel yapısı, ekonomisi ve gereksinimleriyle birlikte coğrafi unsurları da yapının dilini ve uygulama yöntemlerini doğrudan etkiler. Coğrafi yapı ve iklim çeşitliliğinin fazla olması, Anadolu'nun farklı yerlerinde farklı sonuçlar doğmasına neden olmuştur. Tüm bu verilerin bir araya gelmesi, Orta ve Doğu Anadolu'da taş ve kerpicin, Batı Anadolu'da taşın, Güney Anadolu'da ahşap ve taşın, öte yandan Anadolu'nun kuzeyinde ise ahşabın temel yapı malzemeleri olarak kullanılması sonucunu doğurmuştur. Mimari dilin oluşmasında etkili olan çok sayıda etmen olması, geleneksel Türk evinin Anadolu'nun farklı bölgelerinde farklı bölgesel özellikler göstermesini sağlamıştır [3-15].

\subsection{Geleneksel Türk Evlerinin Cephe Özellikleri}

Geleneksel Türk evinin cepheleri, Anadolu'nun farklı bölgelerinin zaman içinde sahip olduğu kendine has kültür birikiminin önemli aktarım unsurlarından biridir. Kent kullanıcılarına yörenin kültüründen, tarihinden, sosyo-ekonomik yapısından ve yapının yapıldığı dönemdeki yapım tekniklerinden, malzemelerden yansımalar sunar. Dönemin bir yansıması olmasının yanı sıra günümüz mimarisine 1 şı tutması açısından da önemlidir.

Geleneksel Türk evlerinin genellikle bir ya da iki katlı olduğu görülmektedir. Bu oluşumu Sedad Hakkı Eldem, "Türk Evi umumiyetle bir katlıdır. Ancak, zaman ile kat adedi fazlalaşmıştır. Öyle olmakla beraber, daima esas kat tektir. Bu esas kat ise birkaç katlı evlerde mutlaka en yukarıdadır. En basit ve alçak ev tiplerinde yalnız bir kat mevcuttur. Bu kat tercihen zeminden bir buçuk iki metre kadar veya daha fazla yüksekte bulunmaktadır." diyerek açıklamıştır [13]. İki veya çok katlı konutlarda giriş katının servis alanları için kullanılıyor olması bu katın cepheye yansımasını daha sade kılarken, üst katın yaşam alanlarını içermesi cepheye de bu katta hareketlilik katmaktadır (Şekil 3). 

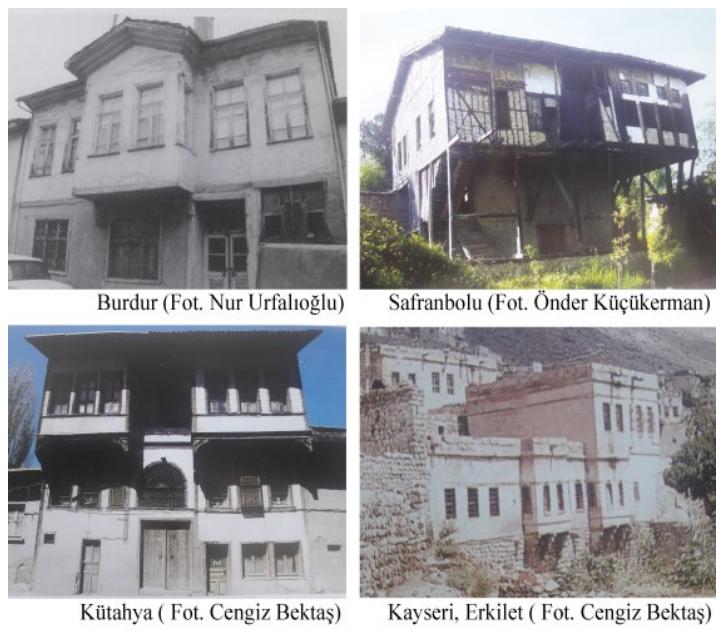

Şekil 3. Anadolu'nun farklı bölgelerinden Türk evleri cephe fotoğrafları [2,3-16]

İç mekanda kullanımı kolaylaştırması, 1şı̆̆ı̆ kullanımı, yapının hava alması gibi gerekçelerle çeşitli çıkmalar yapılmıştır. Çıkmalar, cumbalar, sofanın plandaki uzantıları olan köşk eyvanları plan şemasının dışa yansımaları olarak cephede hareketlilik oluşturan elemanlar olarak karşımıza çıkar (Şekil 4). Bu çıkmaların tarzı ve boyutları da kendi içinde farklılıklar gösterir. Örneğin Akdeniz Bölgesi geleneksel evlerinde iç sofalı plan şeması, yapının cephesine tam ortada ve sıvasız ahşap çıkma şeklinde ya da sofanın üstünde üçgen /yuvarlak alınlıklı olarak yansır [16].

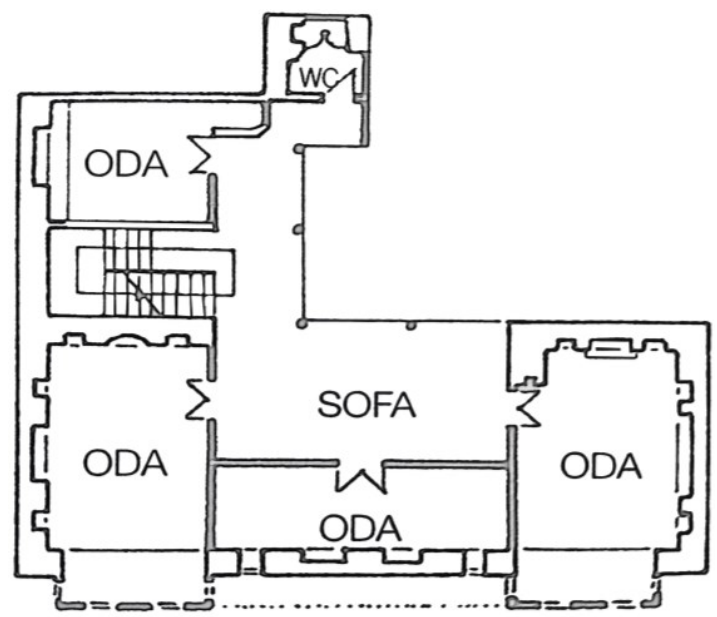

I. kat planı

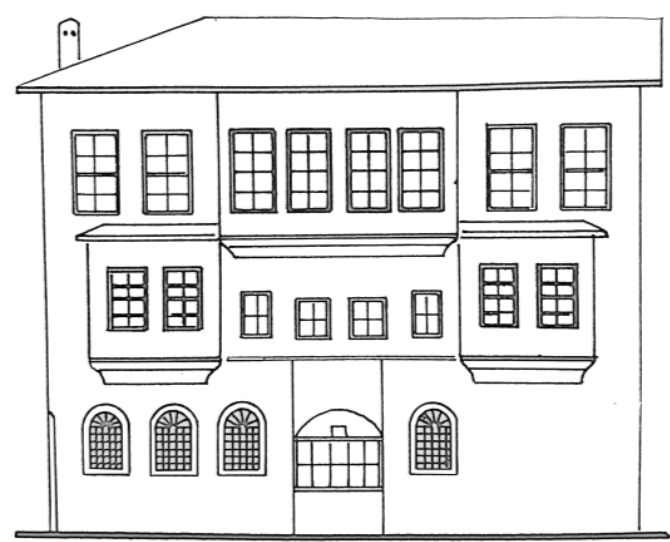

Şekil 4. Geleneksel bir Türk evi örneğinde çıkmaların planda ve cephedeki ilişkisi [16]

Pencere düzenleri de üst katta giriş kattan farklılaşmıştır. Üst katta pencerelerin yol kotuyla göz hizasında bulunmaması pencerelerin daha büyük boyutta, yaşama mekanlarına daha çok 1 şık alacak şekilde olması sonucunu doğururken, servis alanı olan alt katta ise hem kullanım amacı olarak hem de Anadolu kültürünün getirdiği mahremiyetin de etkisiyle daha küçük oranlarda pencerelerin kullanılması sonucunu doğurmuştur. $\mathrm{Bu}$ durum 1s1 değişimlerinin etkisiyle bazen yaşama katında da farklılaşır. Odalar kışlık ve yazlık olarak ayrılır. Evin içindeki konumu ve yönü de düşünülerek oluşturulmuş olan yazlık odanın pencereleri daha büyük olurken, kışlık oda daha korunaklı hazırlanıp pencere oranları küçültülmüştür [3-17,18]. Katlar arasındaki bu farkl1lık başta tezat gibi dursa da sokak-cephe ilişkisini ve uyumunu ortaya çıkaran ve oluşturan asıl etmen olmuştur [17].

Kimi yapı örneklerinde cephedeki çıkmaları takip eden kimi zamanda düz ve bütünsel bir biçimde devam eden saçaklar geleneksel Türk evlerinin bir diğer kendine özgü elemanıdır. Saçaklar ve süslü kenarlıkları, yapıya hareketlilik katan cephe unsurlarındandır. Giriş katın sadeliği cephede uygulanan süslemelerle üst katlarla bir bütün oluşturur. Özellikle 18. yüzyıl sonları ve 19. yüzyılda saçaklar, çıkmalar ve cephenin geneline hâkim olan süslemeler en yoğun halini almıştır [15-17]. 
Evin yapımında tercih edilen yapım tekniği ve kullanilan malzeme de cephe kimliğinin oluşumundaki başka bir etmendir. Anadolu'nun farklı kesimlerinde bölgenin jeolojik yapısına ve iklim özelliklerine göre farklı malzemeler tercih edilmiştir. Kimi zaman giriş katı tamamen taş ile inşa edilmiş, ikinci kat ahşap veya ahşap çatkı arası tuğla ya da kerpiç devam ederken kimi zaman taş temel üzeri kerpiç çıkılmıştır. Bölgeden bölgeye değişen bu farklılıklar Anadolu'nun farklı yerlerinde cephe dilinde farklı sonuçlar doğmasını sağlamıştır.

\section{GELENEKSEL VAN EVLERINIIN CEPHE ÖZELLIKLERİ}

\subsection{Yerleşimin Coğrafyası ve Kısa Tarihi}

Van, Doğu Anadolu Bölgesi'nde siradağların en yoğun olduğu, engebeli bir coğrafyaya sahiptir [19]. Türkiye sınırları içinde bakıldığında ise Doğu Anadolu Bölgesinde yer alan kent Yukarı Murat Van bölümünde yer alır [20].

Kent, Dünya'nın en büyük kapalı havzası olan Van Gölü havzasinda Van Gölü'nü doğudan çevrelemektedir. Hafif eğimli bir alan üzerine kurulmuştur (Şekil 5). Temelinde bulunan paleozoik şist ve kalkerler, bunun yanı sıra yer yer bulunan mezozoik ve tersiyer kütlelerin de etkisiyle dağların göle birbirinden farklı şekilde uzanmış olduğu, girinti ve çıkıntıların fazlaca bulunduğu görülür [4-20].

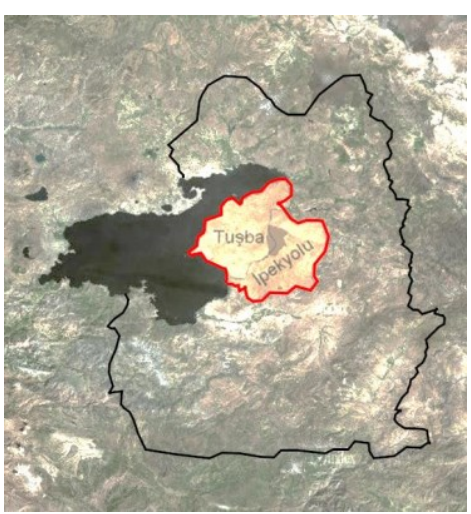

Şekil 5. Tuşba ve İpekyolu ilçelerinin (eski Merkez ilçesi) il sınırları içindeki konumu
Sodalı göllerden biri olan Van Gölü, Van havzasının tabanına yerleşmiştir. Yüzölçümü $3713 \mathrm{~km}^{2}$ ve hacmi $607 \mathrm{~km}^{3}$ 'tür. Bu özellikleriyle Türkiye'nin en büyük gölüdür [21]. Van Gölü bölgenin iklimini doğrudan etkiler. Kışları sert ve soğuk geçer. Yazları ise sıcak olmakla beraber karasal iklimin özelliği olan gece-gündüz sıcaklık farkları etkisini gösterir. Gündüzler sıcakken, akşamları serin bir hava hakimdir. Bölgede ve Van ilinde karasal iklim hâkim olsa da gölün etkisiyle Van diğer bölge kentlerine göre daha 1lıman bir iklime sahiptir. Havzanın en verimli arazileri gölün kıyı kesimlerinde bulunmaktadır [22]. Yaylalar doğudan başlayıp Van Gölü kıyılarına doğru alçalmaktadır [4].

Van tarihinin yazı öncesi devire kadar uzandığı yapılan arkeolojik kazılar ve çalışmalar sonucunda bilinmektedir. Yapılan bu araştırmalar 1şı̆̆ında Van ve çevresinde yapılaşmanın Kalkolitik devire dayandığını ve bu dönemden süregelen bir kültür birikiminin bölgede hâkim olduğunu söylemek mümkündür. Tilkitepe Höyüğü'nde yapılan kazı çalışmaları neticesinde Van'ın Kalkolitik Çağ'da yerleşim yeri olarak kullanıldı ğı anlaşılmıştır [20].

M.Ö. XIII. yüzyıl ve sonrasında bölgeye eski Asurca adıyla Uruatri Nairiler olan Urartuların yerleştiği bilinmektedir. Başkentleri, günümüzde de Van Merkez ilçelerinden biri olan Tuşba'dır (Tuşpa-Thospia) [20]. 133 y1lında Romalılar bölgeyi ele geçirmiştir. M.S. V. yy. itibariyle bu topraklar uzun bir süre Bizans ve Sasaniler arasında git-gel yaşamıştır.

VII. Yüzyılın sonlarından itibaren Van ve çevresi Ermenilerin hakimiyetine geçmiştir. Daha sonra Abbasiler bölgeyi Ermeniye adıyla eyalet valiliği şeklinde idare etmiştir. X. Yüzyıl sonlarında Van ve yöresine tekrar Bizans İmparatorluğu hakim olmuştur. 1064 yılında Melikşah tarafindan Van ve çevresi fethedilmiştir ve Anadolu Selçukluları'nın idaresine geçmiştir.

Sonrasında sirasıyla Moğollar, Karakoyunlular ve Akkoyunlular bölgeye hakim olmuştur. 1534 y1lında ise Kanuni'nin Irakeyn seferinden sonra Safevilerden alınıp Osmanlı topraklarına katılmıştır (Şekil 6) [4]. 


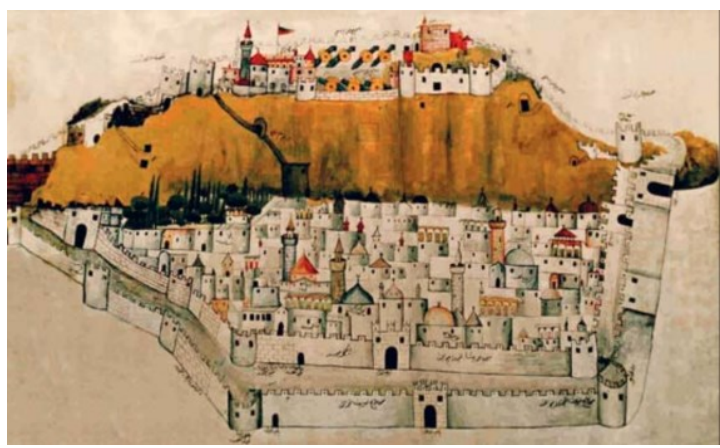

Şekil 6. Van'ın XVII. yüzyıl içindeki durumunu gösteren bir minyatür (TSMA E.n. 9847)

Osmanlı'nın İran sınırında olan kente bu nedenle ayrı bir önem verilerek kent yeni baştan kurulmuş ve Van kalesi onarılmıştır (Şekil 7). 400 yıl süren Osmanlı idaresi sonunda, 1915'te Rus işgaline uğrayan şehir Ermeni isyancılar tarafindan yıkılıp ateşe verilince Van Valisi'nin emri ile boşaltılmıştır. 2 Nisan 1918'de harabe halinde geri alınmıştır. Ancak Erek Dağı eteklerinde yeni Van şehri gelişirken, Eski Van tamamen terk edilmiştir [4].

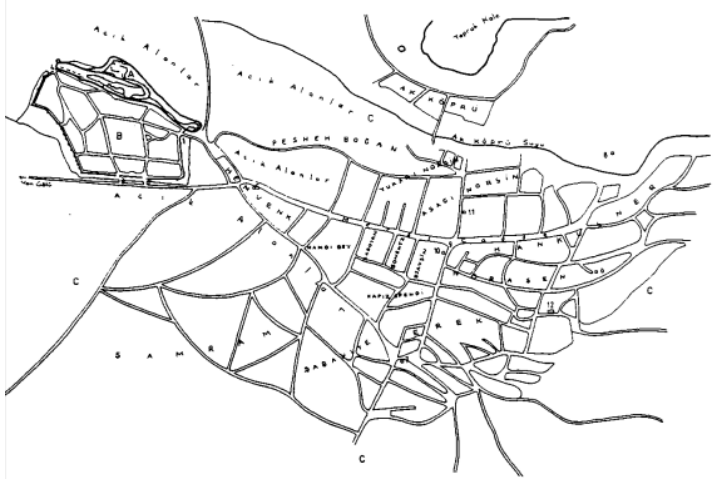

Şekil 7. XIX. Yüzyılda Lynch'in Van kenti yerleşim planı [4]

\subsection{Van'da Konut Mimarisi}

Van konut mimarisi 1915 isyanından önce Kale dibine konumlanmış eski Van şehrinde gelişimini sürdürürken 1915 isyanıyla birlikte konutların hepsi yanmıștır. Eski Van şehrinden geriye kalan fotoğraflar ve gravürler ışığında kentteki evlerin çoğunlukla tek katlı veya iki katlı, düz damlı olarak inşa edildiği anlaşılmaktadır. Evler, kentin küçük bir alanda konumlanmış olması nedeniyle bitişik nizamda yapılmıştır (Şekil 8). Yap1 malzemesi olarak kerpiç kullanılmıştır.

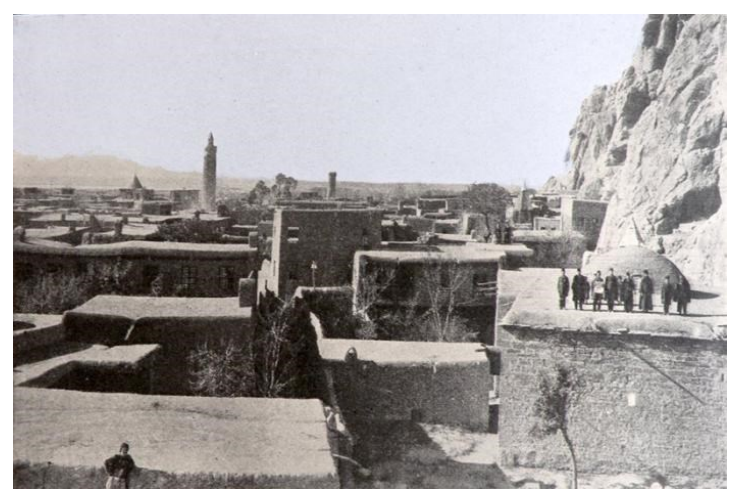

Şekil 8. Eski Van şehri (Kaynak: Anonim)

XX. yüzyıla kadar Müslüman ve Ermeni halk barış içinde kalenin güneyinde konumlanan eski Van şehrinde yaşamıştır. Sonrasında Milliyetçilik akımının etkisiyle Müslüman ve Ermeni halkın anlaşmazlıklar yaşaması ve nüfusun artmasından kaynaklı şehrin arazisinin yeterli gelmemesiyle birlikte kent, daha önce bağ, bahçe olarak kullanılan şehrin etrafındaki arazilere doğru büyümeye başlamıştır. Van'ın bugünkü mahallelerine konutlar yapılmaya başlanmıştır. Bu konutlar eski Van şehrinde olduğu gibi tek katlı ve iki katlı olarak inşa edilmiştir [4]. Genel olarak varlıklı ailelerin iki katlı ve daha büyük evler yaptığı, fakir halkın tek katlı ve daha küçük programlı evler inşa ettiği öne sürülebilir. Tandır evi bulunan evlerde yapı, eve bitişik inşa edilir ya da bahçe içinde yer alır.

Yap1 teknikleri ve kullanılan malzeme seçimleri, Anadolu'nun diğer bölgelerinde de olduğu gibi coğrafi koşullar ve iklim şartları etkisinde oluşmuştur. Geleneksel Van evlerinde yapı malzemesi olarak taş temel üzerine kerpiç kullanılmıştır (Şekil 8). Evler ahşap hatıllı düz damlı olarak inşa edilmiştir. Ahşabın konutta diğer kullanım alanları ise döşemeler, cumbalar, balkonlar, doğramalar ve iç merdivenlerdir. Genellikle iç sofalı plan tipinde inşa edilmişlerdir. 
Kentin hızla büyümesi, iklim ve doğa koşulları etkenleriyle, çoğu büyük tahribat gören ve herhangi bir koruma çalışması yapılmayan Van evlerinin 2011 depremi sonrasında çoğu yıkılmıştır. Ayakta kalmayı başarabilmiş evlerde yıkılma tehlikesi altındadır.

\subsection{Geleneksel Van Evlerinin Cephe Özellikleri ve Tipolojisi}

Geleneksel Van evlerinin cepheleri, evde yaşayan ailenin bir nevi sosyal, kültürel ve ekonomik durumunun bir yansımasıdır. Varlıklı ailelerin yaşadığı evlerin cepheleri süsleme açısından daha zengindir fakat geleneksel Van evlerinin genelinde cepheler yalın tutulmuştur. Giriş cephesi direkt sokağa bakar. Temelden subasman seviyesine kadar taş kullanımını kerpiç duvarlar takip eder. İç ve diş duvarlar çamur ve saman karışımıyla sıvalıdır. Bazı evlerde pencerelerin alt ve üst kenarlarında ve giriş kapısının üstünde bulunan ahşap hatıllar cephe boyunca devam eder.

İki katlı geleneksel Van evlerinin cumbalı ve nadir olarak balkonlu örnekleri de vardır. Cumba ve balkonlar için de yapı malzemesi olarak ahşap kullanılmıştır. Cumbalar cepheye hareketlilik katarken, sokağa bakan yüzeyinde ve yan yüzeylerinde bulunan dikdörtgen pencereler sayesinde de ikinci katta bulunan yaşam alanının doğal ışığı alma kapasitesini artırır.

Pencereler ahşap ve genellikle dikdörtgendir. Kimi evlerde simetrik iken kimi evlerde ise farklı boyutlarda ve asimetrik olması, cephelerde farklı sonuçlar doğurmuştur. Pencerelerin demir lokmalı parmaklıkları bulunur. Parmaklıklara bitkisel motifler işlenerek estetik bir görünüm sağlanmıştır. Bazı evlerde giriş cephesindeki pencere üstlerinde tuğladan yapılmış farklı nitelikte motifler, süslemeler görülür (Şekil 9).
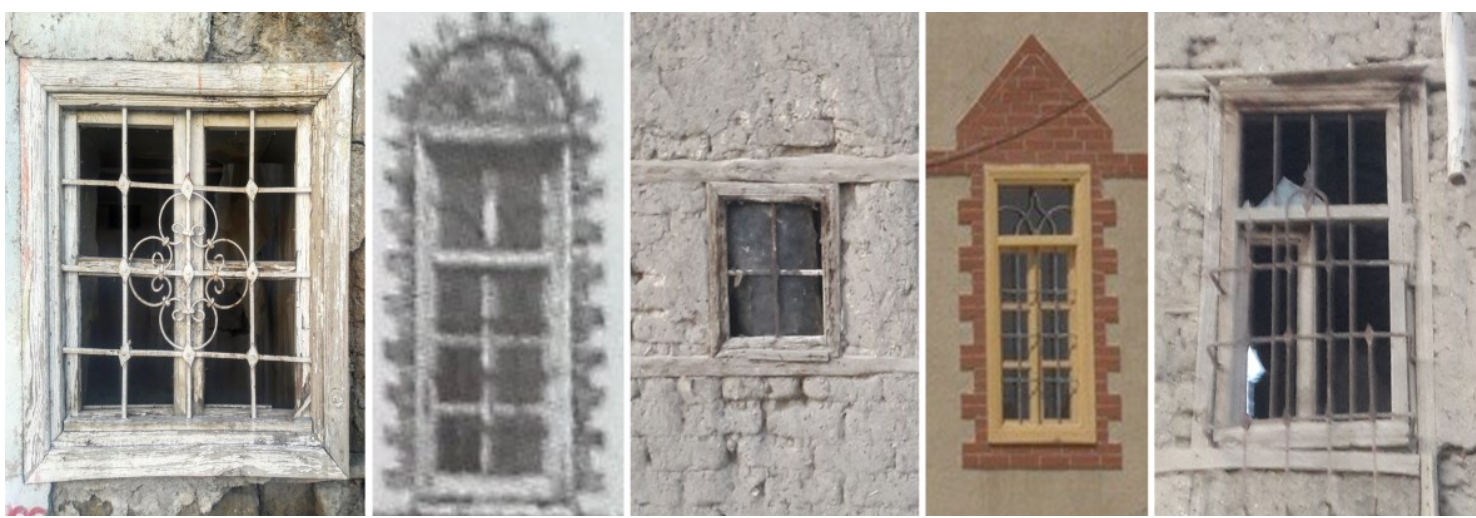

Şekil 9. Van evi ön cephe pencere görünüş örnekleri

Giriş cephesinde bulunan kapılar ahşap ve çift kanatlıdır. Tek katlı evlerde tek kanatlı giriş kapısı bulunan örnekler de mevcuttur. Giriş kapısının üst tarafinda bitkisel motifli metal ferforjeler bulunur (Şekil 10). Çift kanatlı giriş kapısının her iki yanında kesme taştan ya da tuğladan, dikdörtgen veya kare formda geleneksel Van evlerine özgü bölümler bulunur. $\mathrm{Bu}$ bölümler ön cephenin subasman seviyesinin üzerinde, sağ ve sol alt köşelerinde de bulunur. Ahşap pervazlar ile çevrilidirler (Şekil 11, Şekil 12).

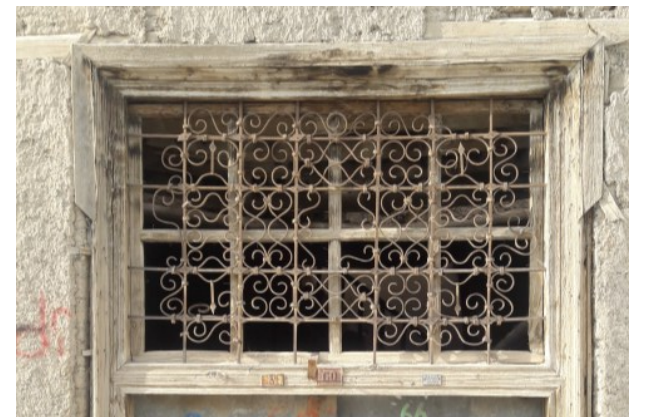

Şekil 10. Van evi giriş kapısı bitkisel motifli metal ferforje görünüşü (Örnek) 


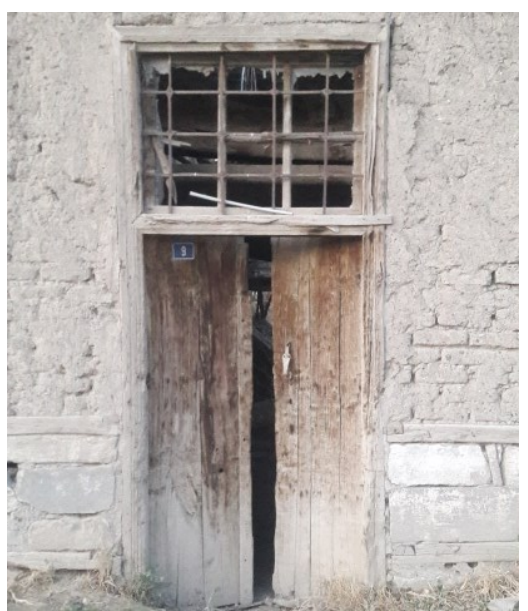

Şekil 11. Van evi giriş kapısı görünüşü (Örnek)

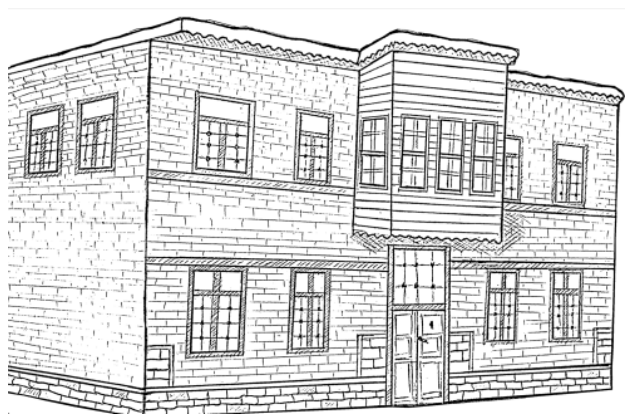

Şekil 12. Bir geleneksel Van evi örneğinin cephe eskizi

Geleneksel Van evinin düz damında, düz ve bütünsel bir biçimde devam eden saçaklar, cumbalı evlerde cumbayı da takip ederek devam eder. Saçaklar ve saçağın altındaki ahşap çörtenler yapıya hareketlilik katan cephe unsurlarındandır (Şekil 13). Kimi evlerde balkon ve cumba altlarında da süslü ahşap kenarlıklar devam eder ve cephe süslemesinde bütünlüğü sağlar.

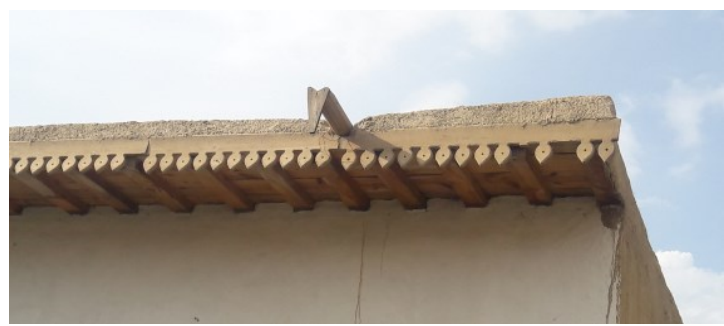

Şekil 13. Van evi ahşap çörten ve süslü saçak kenarlıkları (Örnek)
Geleneksel Van evlerinin cephe düzenlemeleri ve tipolojisi cephe hareketliliğine ve cephede bulunan boşluklara göre iki grupta değerlendirilmiştir (Çizelge 1). Geleneksel Van evlerinin cephelerinin genel olarak sade tutulmuş olması, cumba ve balkondan başka öne çıkan eleman olmayışı sebebiyle konutlar cephe hareketliliğine göre incelenirken cumbasız, cumbalı ve balkonlu olarak sınıflandırılmıştır. Cephede bulunan boşluklara göre değerlendirme yapılırken ise kap1 ve pencerelerin cephe üzerindeki konumlanışı dikkate alınırken, alt ve üst kat pencerelerinin boyutlarının birbirlerine göre olan ve aynı zamanda kendi içlerindeki ilişkileri göz önünde bulundurulmuştur.

Çizelge 1. Geleneksel Van evleri cephe tipolojisi

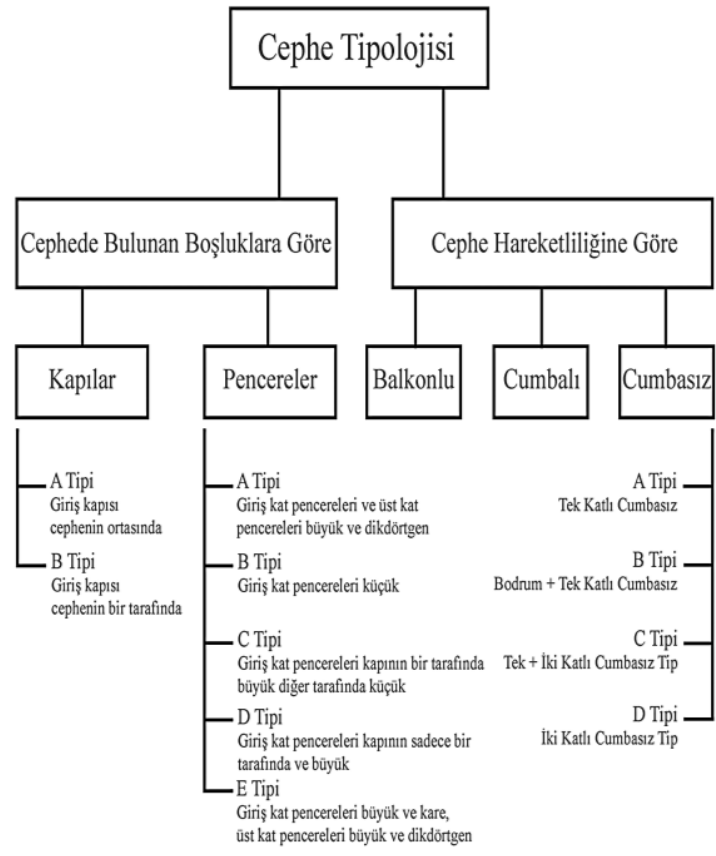

\subsubsection{Cephede Bulunan Boşluklara Göre}

Cepheler, kapı ve pencere düzenlemelerine göre değerlendirilmiştir.

\subsubsection{Kapılar}

Geleneksel Van evlerinde giriş kapılarının genellikle çift kanatlı ve ahşap olduğu görülmektedir. Kapıların cephe üzerindeki konumu 
cephede farklılaşmalar doğurmuştur. Giriş kapısının cephenin ortasında, cumba ya da balkon var ise aynı hizada veya cephenin bir tarafinda olduğu iki durum tespit edilmiştir (Şekil 14).

A Tipi- Giriş kapısı cephenin ortasında

B Tipi- Giriş kapısı cephenin bir tarafında

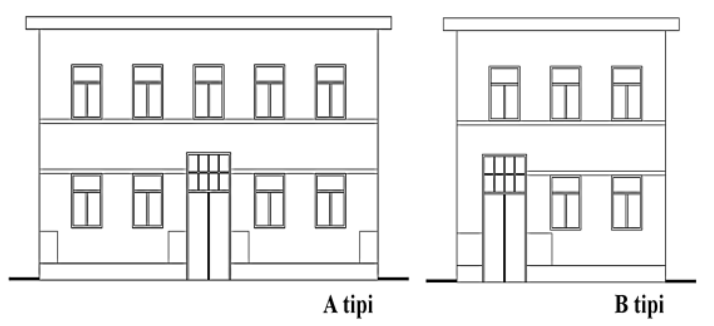

Şekil 14. Giriş kapısı konumuna göre cephe tipolojisi

Cumhuriyet mahallesi Çalık sokakta bulunan ve yapım yılı 1917 olan Şükrü Yörük evi A tipi için, Mercimek mahallesi Mercimek sokakta 1915 yılında yapılmış olan Hacı Hüsnü Yaşar Evi ise B tipine örnek verilebilir (Şekil 15). Buzhane mahallesinde bulunan 1917 yılında yapılmış olan Derviş Demircioğlu evi de B tipinin bir diğer örneğidir.
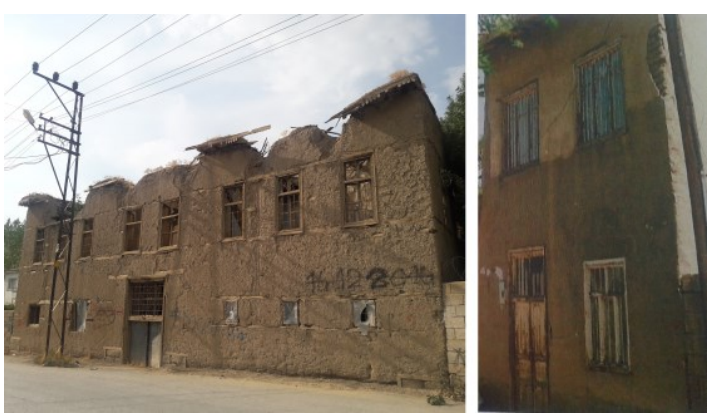

Şekil 15. A Tipi (Şükrü Yörük evi) ve B Tipi (Hacı Hüsnü Yaşar evi) örnekleri

\subsubsection{Pencereler}

Pencere boyutları, oranları ve cephe üzerindeki konumlanmaları giriş katında ve üst katta farklılıklar gösterir. $\mathrm{Bu}$ farklılıklar sonucu bes farklı cephe tipi görülmektedir (Şekil 16).
A Tipi- Giriş kat pencereleri ve üst kat pencereleri büyük ve dikdörtgen

B Tipi- Giriş kat pencereleri küçük

C Tipi- Giriş kat pencereleri kapının bir tarafında büyük diğer tarafında küçük

D Tipi- Giriş kat pencereleri kapının sadece bir tarafında ve büyük

E Tipi- Giriş kat pencereleri büyük ve kare, üst kat pencereleri büyük ve dikdörtgen
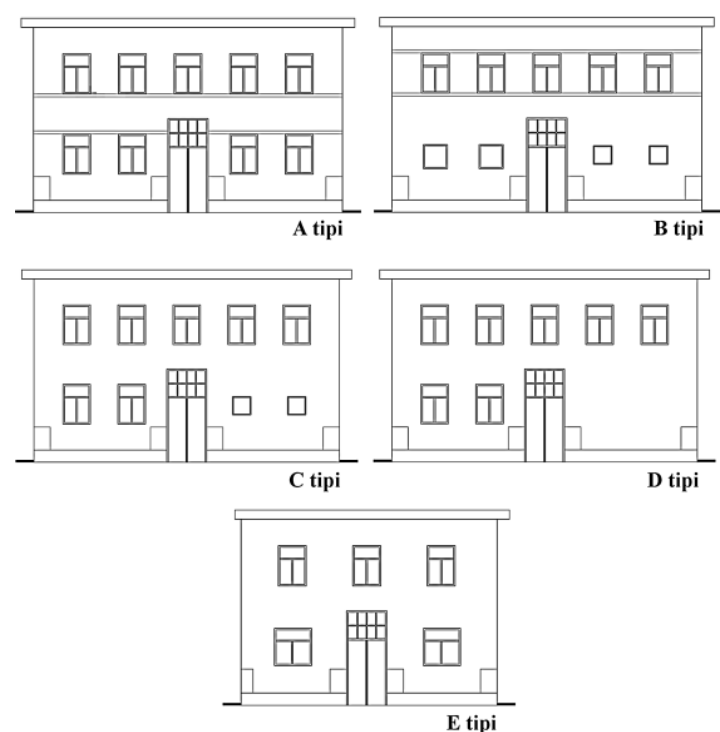

Şekil 16. Pencere boyutları ve konumlarına göre cephe tipolojisi

Projesi Mimar Şahabettin Öztürk tarafından hazırlanan ve Van Kalesi'nin kuzeybatı köşesinde 1998 yılında inşa edilen örnek Van evi ve Hamdi Dinler evi A tipi için, Cumhuriyet mahallesi Çalık sokakta bulunan, yapım yılı 1917 olan Şükrü Yörük evi B tipi için, aynı konumda bulunan ve aynı dönemde inşa edilen Bilal Yörük evi C tipi için, günümüzde tamamen yıkılmış olan, fotoğrafina Van İl Kültür ve Turizm Müdürlüğü arşivinden ulaşılan Abdülelem Arvas evi D tipi için, Bahçıvan mahallesi Eski Banka sokakta 1935 yılında yapılan Yusuf Ziya Kayaçelebi evi E tipi için örnek gösterilebilir (Şekil 17). 

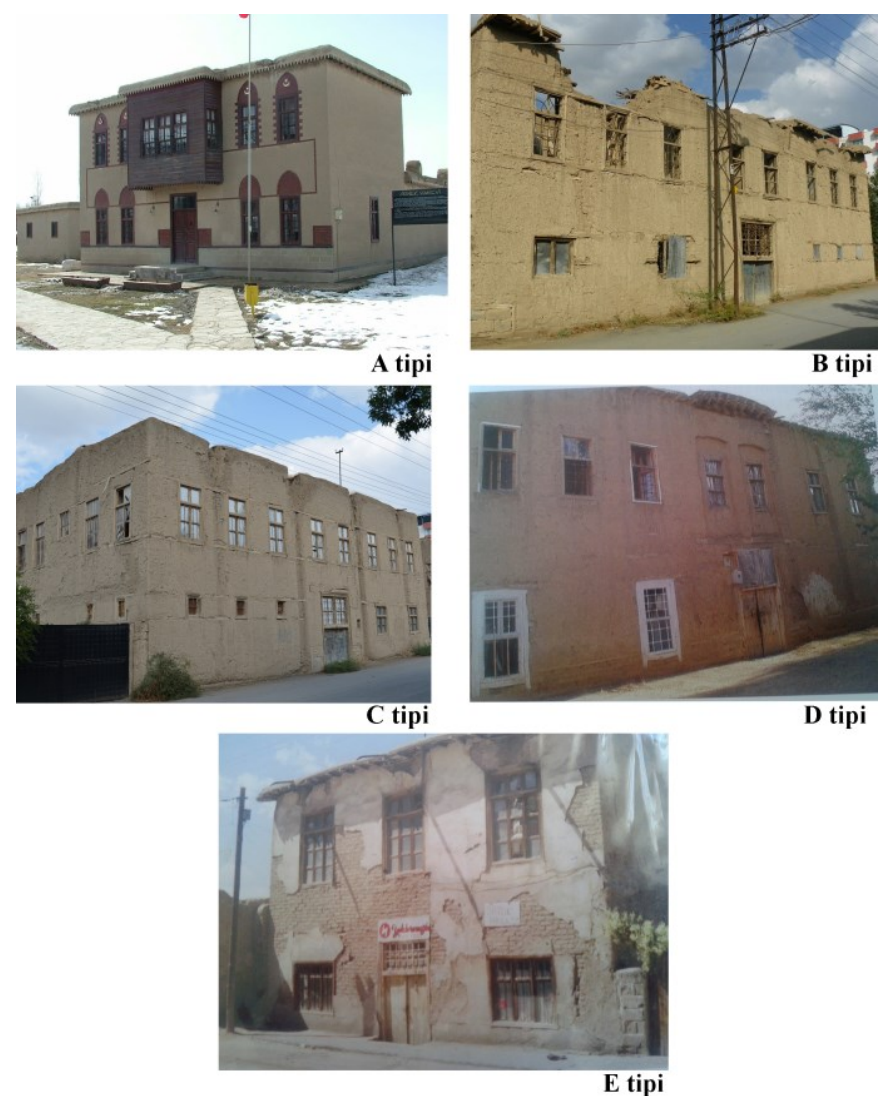

D tipi

E tipi

Şekil 17. Pencere boyutları ve konumlarına göre cephe tipolojisinde örnek evler: A Tipi (Örnek Van evi), B Tipi (Şükrü Yörük evi), C Tipi (Bilal Yörük evi), D Tipi (Yusuf Ziya Kayaçelebi evi)

\subsubsection{Cephe Hareketliliğine Göre}

Geleneksel Van evleri tek ya da iki katlı olarak inşa edilmiştir. İki katlı evlerin bazı örneklerinde ikinci katın giriş katıyla aynı düzlemde devam ettiği görülürken, kimi evlerde ise yaşam alanı olarak kullanılan ikinci katta, sofanın dışa bir uzantısı olarak tanımlanabilecek balkon ya da cumbalar bulunduğu görülür. Bu bulgular ışığında, geleneksel Van evleri cephe hareketliliğine göre üç sınıfta değerlendirilmiştir.

\subsubsection{Balkonlu}

Balkon, geleneksel Van evlerinde çok az rastlanan bir cephe elemanıdır. Üst katın sofasına açılan balkon, cephede giriş kapısının hemen üzerinde konumlanır (Şekil 18).

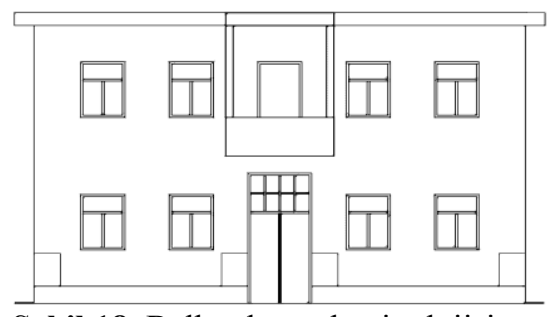

Şekil 18. Balkonlu cephe tipolojisi

Akköprü mahallesi Oğuzlar sokakta bulunan geleneksel Van evinin balkonlu cephesi günümüzde de okunabilmektedir. İçinde yaşayan aile tarafından çok fazla değişikliğe uğramış olan yapının 1940'lı yıllarda inşa edildiği bilinmektedir (Şekil 19). Sıhke caddesinde inşa edildiği bilinen geleneksel Van evi de balkonlu geleneksel Van evlerinin tespit edilen bir diğer örneğidir (Şekil 20). 


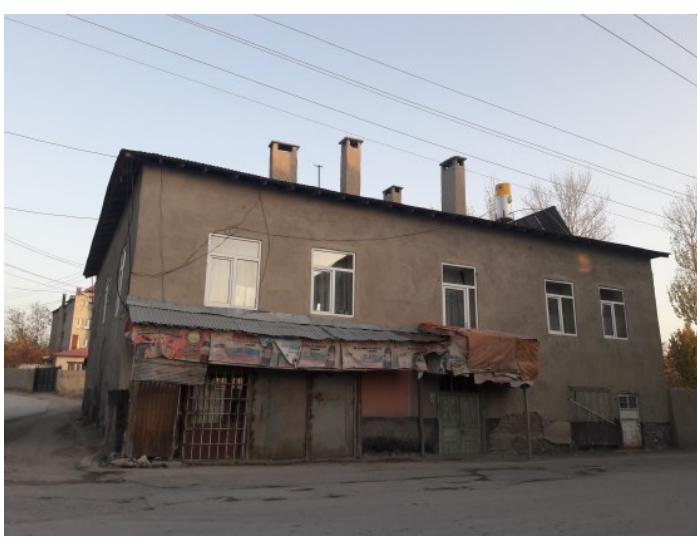

Şekil 19. Balkonlu bir geleneksel Van evi örneği (Akköprü mahallesi, Oğuzlar sokak)

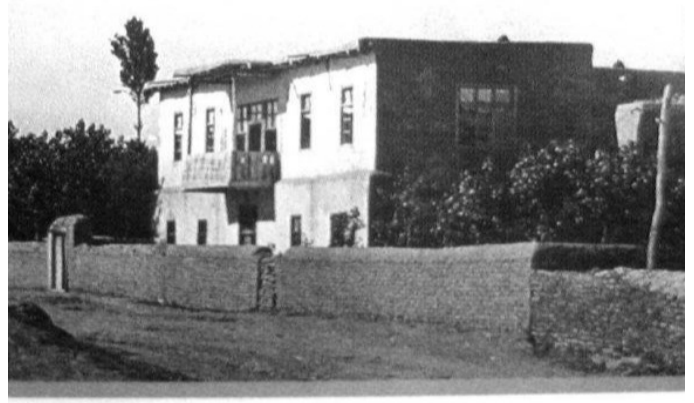

Şekil 20. Sihke caddesinde inşa edilmiş balkonlu bir Van evi (Ümit Kayaçelebi arşivinden)

\subsubsection{Cumbalı}

Doğal 1şı̆̆ın yaşam alanına ulaşma kapasitesini artıran, planın cephede bir yansıması olan ve cepheye hareketlilik katan cumbalar geleneksel Van evlerinde sıklıkla kullanışmış yapı elemanlarından biridir (Şekil 21).

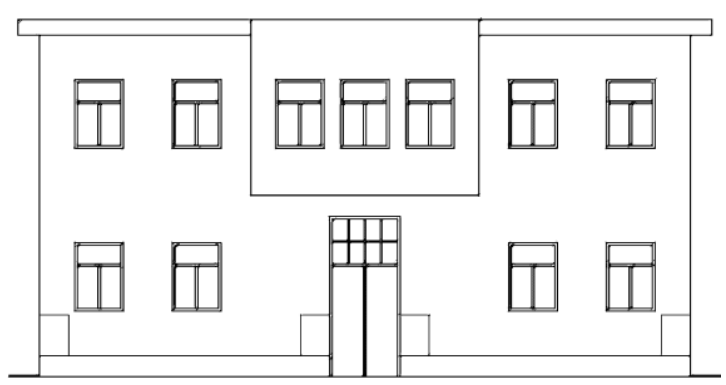

Şekil 21. Cumbalı cephe tipolojisi
Selim Bey mahallesinde eski Kale yolu üzerinde 1907 y1lında inşa edilmiş olan Mustafa Dilaver evi (Şekil 22), Akköprü mahallesi Orta sokakta bulunan 20. yüzyılın ilk çeyreğinde inşa edildiği bilinen Kerem Döner evi (Şekil 23), Bahçıvan mahallesi Hamza Dayı sokakta 1940'lı yıllarda yapılmış olan Mustafa Güngörer evi ve 1998 yılında örnek Van evi projesi olarak inşa edilen yapı cumbalı geleneksel Van evi örneklerindendir.

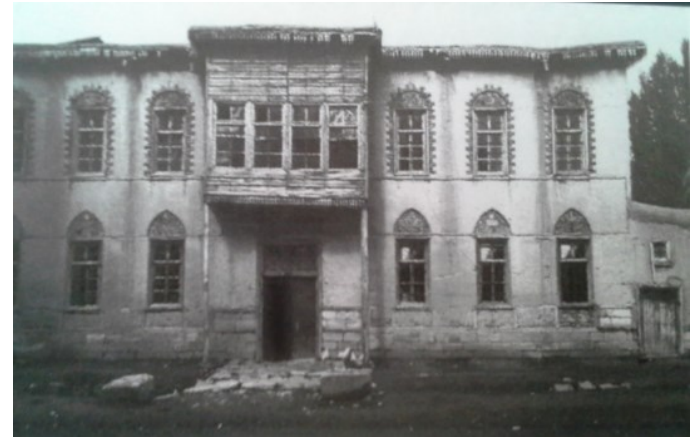

Şekil 22. Mustafa Dilaver evi (Ümit Kayaçelebi Arşivinden)

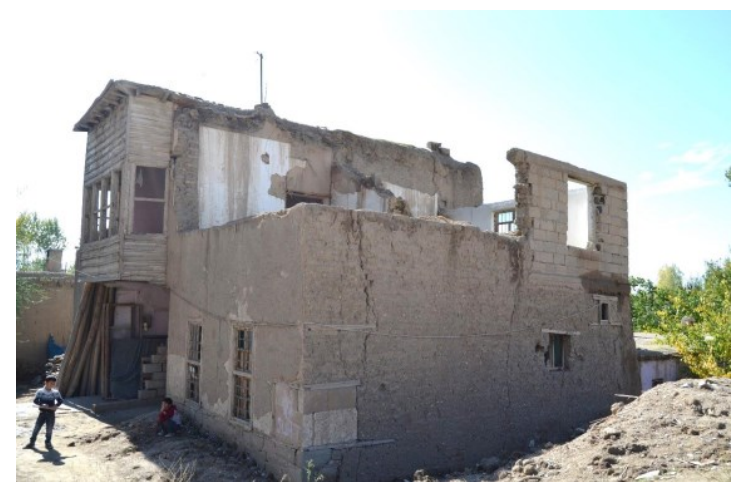

Şekil 23. Kerem Döner Evi (Fot. Oktay Başak)

\subsubsection{Cumbasiz}

Tek katlı ve iki katlı örneklerinin olduğu, iki katlılarda giriş kapısının bir ya da iki üst kat penceresi ile hizalandığ 1 cumbasız geleneksel Van evleri dört tip olarak tespit edilip değerlendirmeye alınmıştır (Şekil 24).

\section{A Tipi- Tek Katlı Cumbasız}

B Tipi- Bodrum + Tek Katlı Cumbasız 
C Tipi- Tek + İki Katlı Cumbası Tip

D Tipi- İki Katlı Cumbasız Tip
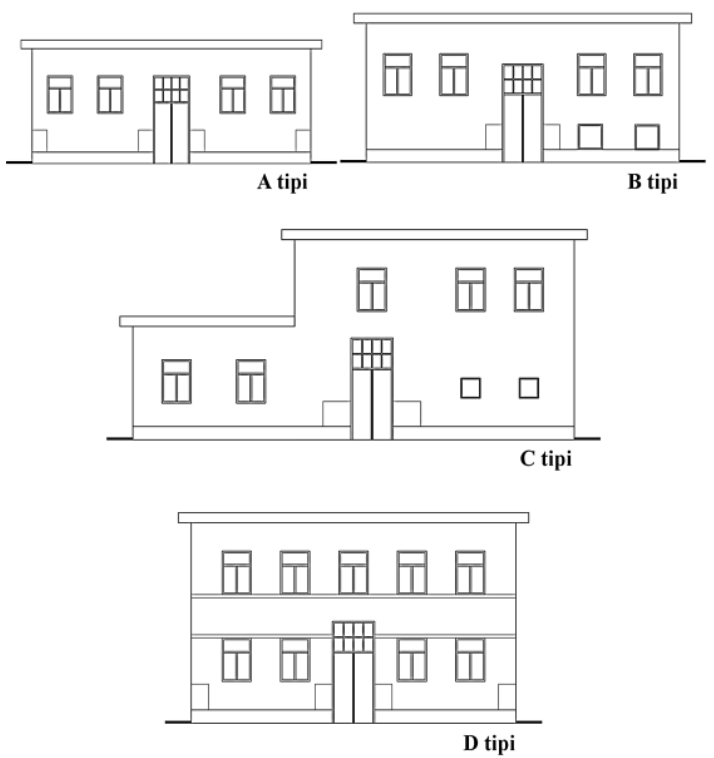

Şekil 24. Cumbasız evlerin kat sayısı ve yapı yüksekliklerine göre cephe tipolojisi
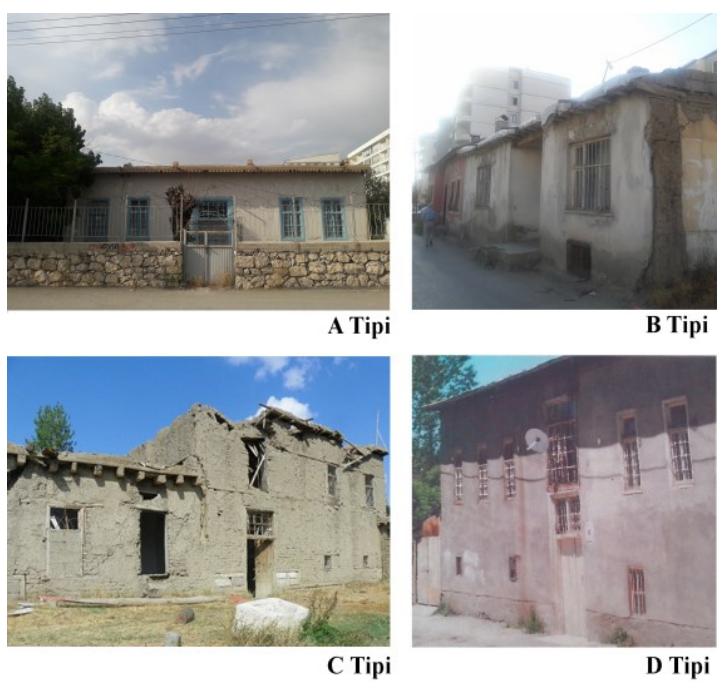

Şekil 25. Cumbasız geleneksel Van evleri tipolojisinde örnek evler: A Tipi (Abdurrahman Yörük evi), B Tipi (Vali Mithat Bey mahallesinde bulunan ev) $\mathrm{C}$ Tipi (Hacı Derviş Demircioğlu evi), D Tipi (Terzi Refik Tüfekçi Evi)
Cumhuriyet mahallesi Çalık sokakta bulunan ilk yapım tarihi 1936 olan Abdurrahman Yörük evi, Vali Mithat Bey mahallesi Ekinci sokakta bulunan Hamit Ekinci Evi ve Hafiziye mahallesi Gölbaşı caddesinde bulunan 1950'li yıllarda inşa edildiği bilinen Hacı Mustafa Topçiçek evleri (2 Adet) A tipi için, Vali Mithat Bey mahallesi Ekinci sokakta bulunan ev B Tipi için, Buzhane mahallesi Nejdet sokakta bulunan 1917 yılında yapılmış olan Hacı Derviş Demircioğlu evi ve Hafiziye mahallesi Türk Özü sokakta 20. yüzyılın ikinci çeyreğinde inşa edildiği bilinen Vasfi Güngören evi C Tipi için, Şabaniye mahallesinde 1942 yılında inşa edilmiş Terzi Refik Tüfekçi evi ve Hafiziye mahallesi 333. Sokakta bulunan 1949 yılında inşa edilen Necmettin Aşıkselimoğlu evi ise D Tipi için örnek evlerdir (Şekil 25).

\section{SONUC VE ÖNERILLER}

Kentlerin kimliğini oluşturan tarihi yapılar öncelikle cepheleriyle kent kullanıcısının hafizasinda yer etmektedir. $\mathrm{Bu}$ nedenle cephenin kentsel mekanların tanımlanmasındaki rolü de büyüktür. Van'in kent dokusunun oluşumunda da geleneksel Van evlerinin cephe dili ve kompozisyonu önemli bir anlam taşımaktadır.

Geleneksel Türk evinin özelliklerini içinde barındıran, günümüze ulaşmış geleneksel Van evlerinin yapım tarihleri çoğunlukla 1915 Ermeni isyanı ve yangınından sonrasına dayanmaktadır. Van kent dokusunun önemli mirasçılarından biri olan geleneksel Van evinin yapımında taş, kerpiç ve ahşap malzeme kullanılmıştır. Yapım tekniği olarak taş temel üzerine kerpiç duvarlar örülmüştür. Ahşap hatıl destekli düz damlarla örtülü olan Van evlerinin günümüzde bazı örneklerinde görülen kırma çatılar sonradan eklenmiştir. Plan tipi olarak çoğunlukla iç sofalı plan tipinde düzenlenmiş, tek katlı veya iki katlı olarak inşa edilmişlerdir. Van konut mimarisi, yapım tekniği ve malzeme kullanım biçimleri açısından bölgenin diğer kentlerinden farklılaşmıştır. Bölgede temel yap1 malzemesi olarak tercih edilen taşın yerine geleneksel Van evlerinde kerpicin kullanıldığ Geleneksel Van evleri, aynı bölgede bulunan Bitlis ve Erzurum evlerinin plan oluşumu ve yap1 
malzemesi kullanımından tamamen farklılaşırken, Erzurum evlerinde de yer alan tandır evi ve tandır evinin yapıya bitişik olarak inşa edilmesi açısından benzerlik göstermektedir. Cephe düzenlemesi olarak daha çok Akdeniz ve İç Anadolu bölgesinde bulunan evlerle benzerlik gösterir. Antalya ve Isparta evlerinin cumbalı/köşklü cepheleri, Konya evlerinin köşk çıkıntı bölümleri geleneksel Van evlerinin mimarisiyle benzerlik taşır. $\mathrm{Bu}$ bölgelerde bulunan evlerin cephe ve malzeme açısından gösterdiği benzerlik, plan düzenlemesi ve süslemeler yönünden bakıldığında geleneksel Van evlerinden farklılaşır. Geleneksel Van evlerinde iç mekân ve diş cepheler oldukça yalındır [16-26].

Çalışmada geleneksel Van evlerinin cephe özellikleri irdelendikten sonra, cephe organizasyonunun oluşmasındaki belirleyici faktörler tespit edilmiş ve tipolojinin belirlenmesinde baz alınan değişkenlere ulaşılmıştır. Cephe'de bulunan boşluklar ve cephe hareketliliği, tipolojinin oluşturulmasındaki ana değişkenler olarak belirlenmiştir. Cephe'de bulunan boşluklara göre değerlendirilen evlerde, giriş kapısı ve pencerelere göre iki sınıfta değerlendirme yapılmıştır. Giriş kapısının cephe üzerindeki konumu baz alınarak; cephenin ortasında veya bir tarafında olduğu örnekler olarak ikiye ayrılmıştır. Pencerelerin boyut ve konumlarına göre; giriş kat pencereleri ve üst kat pencereleri büyük ve dikdörtgen, giriş kat pencereleri küçük, giriş kat pencereleri kapının bir tarafında büyük diğer tarafında küçük, giriş kat pencereleri kapının sadece bir tarafında küçük, giriş kat pencereleri büyük ve kare üst kat pencereleri büyük ve dikdörtgen olan örnekler olarak beşe ayrılmıştır. Cephe hareketliliği değişkeni ise balkonlu, cumbalı ve cumbasız olarak üçe ayrılırken; cumbasız evler tek katlı cumbası, bodrum+tek katlı cumbası, tek+iki katlı cumbasız ve iki katlı cumbasız tip olarak dörde ayrılmıştır.

Geleneksel Van evlerinin çoğunda giriş kapısının cephenin ortasından sofaya açıldığı ve cephede simetri oluşturduğu görülür. Çift kanatlı ve ahşap giriş kapılarının üstünde bırakılan süslü lokma demir parmaklıklı açıklık sofanın aydınlanmasını sağlarken pencerelerle bütünlük olușturmuştur. Cephenin bir tarafından iç mekâna açılan giriş kapılarının örnekleri daha azdır. Mekân kurgusunun değiştiği bu evlerde genel yap1 özelliklerinin giriş kapısının ortadan açıldığ evlerle benzer olduğu görülmektedir. Giriş kapısı simetri ekseninin sağında veya solunda bırakılmıştır. Çoğunlukla sol tarafın tercih edildiği tespit edilmiştir.

Giriş cephe pencereleri ahşap ve demir lokma parmaklıklıdır. Bu parmaklıkların çeşitli bitkisel motif ve bezemelerle işlendiği görülür. Çoğunlukla üst kat pencerelerinin dikdörtgen ve aynı özelliklerde kullanıldığı görülürken, giriş katı pencerelerinin farklılaştığı belirlenmiştir. Bu farklılaşma iç mekanın kullanım farklılıklarının bir yansıması olarak ortaya çıkmıştır. Balkonlu geleneksel evlere çok az rastlanmıştır. Evlerin çoğunlukla cumbalı veya cumbasız, çıkmasız olduğu görülmüștür. Cumbasız evlerde ise tek katlı cumbasız ve iki katlı cumbasız tipin yoğunlukta olduğu tespit edilirken, bodrum+tek katlı konut örneğine bir adet rastlanmıştır.

Kentin kültür birikiminin günümüze ve gelecek nesillere aktarılmasında önemli bir mimari değere sahip olan geleneksel Van evleriyle ilgili yapılan literatür taraması sonucunda yeterli çalışma yapılmadığ1 görülmüştür. Yetkili kurumlardan alınan bilgilere göre bu yapılardan sadece bir tanesinin tescilli olduğu, diğer evlerle ilgili bir tescil, tespit ve koruma çalışması yapılmadı̆̆ anlaşılmıştır. 2011 yılında yaşanan Van depremi, iklim koşulları ve kentte hızla devam eden yapılaşma sürecinde geleneksel Van evlerinin imar planında dikkate alınmayışı, evlerin çoğunun yıkılmasına ve ayakta kalan örneklerinin de büyük tahribat görmesine neden olmuştur. $\mathrm{Bu}$ kapsamda geleneksel Van evleri için tescil, tespit ve koruma çalışmalarının yapılması ve kentin kültürel mirasları olan evlerin kent açısından önemi hakkında kent kullanıcılarının da bilinçlendirilmesi gerekmektedir.

$\mathrm{Bu}$ araştırma geleneksel Türk evlerindeki cephe çalışmalarına ve Van konut örneğine katkı sağlamakta olup, daha sonra yapılacak geleneksel 
Türk evi ve geleneksel Van evleri çalışmalarına bir kaynak niteliği taşımaktadır.

\section{KAYNAKLAR}

1. Kuban D., 1995. Mimarlık Kavramları (Üçüncü Baskı), Yem Yayınevi, İstanbul.

2. Bektaş, C., 1996, Türk Evi, Yap1 Kredi Yayınları, İstanbul.

3. Küçükerman, Ö., 2007. Kendi Mekanının Arayışı İçinde Türk Evi, Türkiye Turing ve Otomobil Kurumu, İstanbul.

4. Uluçam, A., 2000. Orta Çağ ve Sonrasında Van Gölü Çevresi Mimarlığı, Türk Tarih Kurumu Basımevi, Ankara.

5. Uşma, G., Urfalıŏlu, N., 2017. Ömer Selçuk Evi ve Hamit Ekinci Evi Örneği Üzerinden Geleneksel Van Evlerinin Günümüzdeki Durumu, 2. International Mediterranean Science and Engineering Congress, Çukurova University, Adana, 1152.

6. Hasol, D., 2012. Ansiklopedik Mimarlik Sözlüğü, YEM Yayınları, 106, İstanbul.

7. Sönmez, M., 2013. Çağdaş Mimarlıkta CepheYüzey Kavramı Tartışmaları, NWSA Social Sciences, 8 (2), 79-90.

8. Şenyiğit. Ö., 2010. Biçimsel ve Anlamsal Iffade Araci Olan Cephelerin Değerlendirilmesine Yönelik Bir Yaklaşım: İstanbul'da Meşrutiyet ve Halaskargazi Caddeleri'ndeki Cephelerin İncelenmesi, Doktora Tezi, Yıldız Teknik Üniversitesi, Fen Bilimleri Enstitüsü, İstanbul.

9. Atalan, Ö., 2016. Continuity of Regional Identity: A Case Study of Facade Elements in Traditional Çeşme Houses, A/Z Dergisi, 13(2), 121-131.

10. Atıcı, E., 2017. Eskişehir Odunpazarı Evlerinin Cephe Dili Üzerinden İncelenmesi, Sanat Tarihi Dergisi, 26(1), 1-26.

11. Tanyeli, U., 1997. Modernizm'in Sinırları ve Mimarlık, Modernizm'in Serüveni, Ed: Enis Batur, Yapı Kredi Yayınları, İstanbul, 63-71.

12. Kıyıc1, M., 1998. Endüstri Devriminin Osmanlı Mimarlığına Etkileri (1847-1920), Yüksek Lisans Tezi, Yıldız Teknik Üniversitesi, Fen Bilimleri Enstitüsü, İstanbul.
13. Eldem, S.H., 1995. Türk Evi Plan Tipleri, İstanbul Teknik Üniversitesi, Mimarlık Fakültesi Yayını, İstanbul.

14. Günay, R., 1998. Türk Ev Geleneği ve Safranbolu Evleri, Yem Yayınları, İstanbul.

15. Sezgin, H., 2006. Yöresel Konut Mimarisi ve Türkiye'deki Örnekleri Hakkında, Tasarım Kuram Dergisi, 3(4), 1-20.

16. Urfalığlu, N., 2010. Antalya, Isparta ve Burdur Evlerinde Cephe Biçimlenişi, Suna-İnan Kıraç Akdeniz Medeniyetleri Araştırma Enstitüsü Yayınları, Antalya.

17. Kuban, D., 1995. Türk Hayatlı Ev, Ziraat Bankası Yayınları, İstanbul.

18. Perker Z. S., 2012. Geleneksel Cumalıkızık Konutlarında Cephe Özellikleri ve Günümüzdeki Durum, 6. Ulusal Çatı \& Cephe Sempozyumu, Uludağ Üniversitesi Mühendislik ve Mimarlık Fakültesi, Bursa, $1-10$.

19. Erzen, A., 1992. Doğu Anadolu ve Urartular, TTK Yayınları, Ankara.

20. Abdülkadiroğlu, A., 1993. Van Kütüğü, Yüzüncü Yıl Üniversitesi Yayınları, Van.

21. Gürbüz, O., 1994. Van Gölü Çevresinin Coğrafyası (Beşerî ve İktisadi Coğrafya Açısından), Doktora Tezi, İstanbul Üniversitesi Sosyal Bilimler Enstitüsü, İstanbul.

22. Mangaltepe, İ., 2005. XIX. Yüzy1l Fransız Seyyahlarına Göre Van, Doktora Tezi, İstanbul Üniversitesi Sosyal Bilimler Enstitüsü, İstanbul.

23. Sayan, Y., Öztürk, Ş., 2001, Bitlis Evleri, Kültür Bakanlığı Yayınları, Ankara.

24. Öztürk, Ş., Sayan, Y., 1996, Bitlis'in Tarihi Evlerine Bir Bakış, Van Gölü Çevresindeki Kültür Varlıkları Sempozyumu Bildirileri, Van, 101-129.

25. Berk, C., 1951, Konya Evleri, İstanbul Teknik Üniversitesi Mimarlık Fakültesi Yayınları, İstanbul.

26. Karpuz, H., 1984, Türk İslam Mesken Mimarisinde Erzurum Evleri, Kültür ve Turizm Bakanlığı Yayınları, Ankara. 
